\title{
Pendampingan Pengembangan Kentang di Dataran Medium Desa Santong-Kabupaten Lombok Utara
}

\author{
M. Sarjan ${ }^{1 *}$, Aluh Nikmatullah², Mery Windarningsih ${ }^{2}$ Agus Purbatin Hadi ${ }^{3}$ \\ ${ }^{1}$ Pascasarjana, Universitas Mataram, Mataram, Nusa Tenggara Barat, Indonesia \\ ${ }^{2}$ Program Studi Agroekoteknologi, Fakultas Pertanian, Universitas Mataram, Mataram, Nusa Tenggara Barat, Indonesia \\ ${ }^{3}$ Program Studi Ilmu Komunikasi Universitas Mataram, Mataram, Nusa Tenggara Barat, Indonesia.
}

DOI: https://doi.org/10.29303/ujcs.v2i1.24

\section{Article Info}

Received: January 10th, 2021

Revised: February 28th, 2021

Accepted: March 4th 2021

\begin{abstract}
Abstrak: Pengembangan tanaman kentang di Provinsi Nusa Tenggara Barat selama ini dilakukan di dataran tinggi Sembalun. Namun demikian, wilayah Sembalun menghadapi keterbatasan daya dukung sarana prasarana, sehingga salah satu strategi untuk meningkatkan produksi kentang adalah dengan memperluas pengembangan kentang ke kawasan di luar wilayah Sembalun, yaitu ke kawasan dataran medium potensial. Kabupaten Lombok Utara memiliki dataran medium yang potensial untuk pengembangan tanaman kentang, yaitu di wilayah Santong Kecamatan Kayangan dan wilayah Senaru Kecamatan Bayan. Tim Penelitian Unggulan Strategis Nasional (PUSNAS) Universitas Mataram telah melakukan penelitian untuk pengembangan benih kentang bermutu di wilayah Santong, dilanjutkan dengan pendampingan pengembangannya. Hasil pendmpingan ini menunjukkan dari aspek budidaya tanaman kentang dapat tumbuh dan berproduksi dengan baik, namun kendala yang dihadapi adalah tingginya intensitas serangan organisme pengganggu tanaman (OPT). Perluasan ke dataran medium ini menuntut inovasi teknologi produksi kentang di dataran medium. Oleh karena itu, dipandang perlu untuk melakukan pendampingan berkelanjutan pengembangan kentang di Kabupaten Lombok Utara.

Kata Kunci: Pendampingan; Kentang; Dataran medium; Lombok Utara.

Abstract: The development of potato crops in West Nusa Tenggara Province has been carried out in the Sembalun plateau. However, the Sembalun region faces limited infrastructure support capacity, so one of the strategies to increase potato production is to expand potato development to areas outside the Sembalun region, namely to potential medium plain areas. North Lombok regency has a potential medium plain for the development of potato crops, namely in the santong area of Kayangan subdistrict and Senaru area of Bayan Subdistrict. The National Strategic Excellence Research Team of Mataram University has conducted research for the development of quality potato seeds in the Santong region, followed by the assistance of its development. The results of this sideways show from the aspect of potato cultivation can grow and produce well, but the obstacle faced is the high intensity of attacks of plant destruction organisms. The expansion into this medium plain demands technological innovation of potato production in the medium plain. Therefore, it is considered necessary to conduct sustainable assistance of potato development in North Lombok Regency.
\end{abstract}

Keywords: Mentoring; Potatoes; Medium plains; North Lombok.

Citation: Sarjan, M., Nikmatullah, A., Windarningsih, M., \& Hadi, A. (2021). Pendampingan Pengembangan Kentang di Dataran Medium Desa Santong-Kabupaten Lombok Utara. Unram Journal of Community Service, 2(1), 6-11. doi:https://doi.org/10.29303/ujcs.v2i1.24

\section{Pendahuluan}

Kentang (Solanum tuberosom L.) merupakan salah satu pangan utama dunia setelah padi, gandum, dan jagung serta termasuk salah satu komoditas hortikultura yang mendapat prioritas pengembangan di Indonesia. Bagi masyarakat Indonesia, kentang (Solanum tuberosum) sudah tidak asing untuk dikonsumsi sebagai sayuran maupun sebagai sumber karbohidrat pengganti nasi. Di Indonesia, kentang umumnya diperdagangkan dalam bentuk segar dan beberapa jenis olahan, seperti keripik kentang, french

\footnotetext{
*Email: msarjan@unram.ac.id
} 
fries (kentang goreng), dan aneka macam makanan ringan. (AAK, 1992; Idawati, 2012; Rukmana, R. 2002)

Tanaman kentang di Indonesia kini sudah dijadikan sebagai salah satu sayuran yang mendapat prioritas untuk dikembangkan. Hal ini disebabkan permintaan kentang dari tahun ke tahun cenderung meningkat seiring dengan pertambahan penduduk, peningkatan pendapatan, perubahan gaya hidup masyarakat yang menyukai makan di restoran fast food dan berkembangnya industri pengolahan kentang. Kentang banyak mengandung vitamin, seperti vitamin B1, B2 dan vitamin C, serta protein yang sangat baik bagi tubuh. Selain itu, kentang juga mengandung karbohidrat yang cukup tinggi sehingga dapat digunakan sebagai salah satu bahan makanan pokok di dunia (Rukmana, 2002; Sinung, 1989)

Selain dapat digunakan sebagai sumber karbohidrat dalam program diversifikasi pangan, kentang mempunyai nilai perdagangan domestik dan potensi ekspor yang cukup baik. Produksi kentang di Indonesia dalam tiga tahun terakhir meningkat dari 1.094.240 ton pada tahun 2012 menjadi 1.124.282 ton pada Tahun 2013 dan 1.316.016 ton pada tahun 2014 (BPS, 2015). Namun demikian, produksi kentang nasional tersebut baru dapat memenuhi $10 \%$ konsumsi kentang nasional yang terus meningkat setiap tahunnya, yaitu 8,9 juta Ton per tahun (Wattimena, 2000). Oleh karenanya, pemerintah berupaya meningkatkan produksi kentang dalam negeri baik melalui intensifikasi maupun ekstensifikasi (Badan Pusat Statistik. 2015; BPSB TPH Provinsi NTB. 2015)

Terbatasnya produksi kentang nasional disebabkan karena berbagai kendala teknis dan nonteknis. Kesesuaian agroklimat merupakan salah satu pembatas sehingga benih kentang hanya dapat diproduksi di kawasan dataran tinggi atau medium saja. Kentang bisa tumbuh dengan sempurna di dataran tinggi, yaitu berkisar antara 1.600 hingga 3.000 meter diatas permukaan laut. Oleh karena itu, pengembangan tanaman kentang di Provinsi Nusa Tenggara Barat selama ini dilakukan di dataran tinggi Sembalun. Namun demikian, wilayah Sembalun menghadapi keterbatasan daya dukung sarana prasarana, sehingga salah satu strategi untuk meningkatkan produksi kentang adalah dengan memperluas pengembangan kentang ke kawasan di luar wilayah Sembalun, yaitu ke kawasan dataran medium potensial (BPSB TPH Provinsi NTB. 2015, Sarjan et al, 2017).

Kabupaten Lombok Utara memiliki dataran medium yang potensial untuk pengembangan tanaman kentang, yaitu di wilayah Santong Kecamatan Kayangan dan wilayah Senaru Kecamatan Bayan. Tim Penelitian Unggulan Strategis Nasional (PUSNAS) Universitas Mataram telah melakukan penelitian untuk pengembangan benih kentang bermutu di wilayah Santong, dan menyimpulkan dari aspek budidaya tanaman kentang dapat tumbuh dan berproduksi dengan baik, namun kendala yang dihadapi adalah tingginya intensitas serangan organisme pengganggu tanaman (OPT) (Sarjan et al, 2017; Sembel, D. T, 2014)

Perluasan ke dataran medium ini menuntut inovasi teknologi produksi kentang di dataran medium. Oleh karena itu, dipandang perlu untuk melakukan kaji terap pengembangan kentang di Kabupaten Lombok Utara (Sarjan et al, 2018).

Berdasarkan anlisis situasi, salah satu sasaran strategis pembangunan Kabupaten Lombok Utara adalah meningkatnya pertumbuhan ekonomi dan mengurangi kemiskinan dengan menjadikan pariwisata sebagai lokomotif penggerak ekonomi. Sasaran tersebut akan dicapai melalui berbagai program termasuk pengembangan komoditas hortikultura pendukung pariwisata dan penumbuhan wirausaha baru. Dataran medium Kabupaten Lombpok Utara, selain memiliki potensi agroklimat yang baik untuk tanaman hortikukltura, juga merupakan daerah tujuan wisata, terdapat air terjun (Sendanggile, Tiu Kelep, Tiu Sekeper, Tiu Teja, Kertagangga), wisata alam tematik (Kampung Coklat Senara, Kampung Stroberi Subak Sepulu), serta merupakan jalur pendakian ke Gunung Rinjani.

Salah satu komoditas hortikultura yang dibutuhkan oleh pariwisata (hotel dan restaurant) dan adalah kentang. Dengan demikian, produksi kentang di daerah ini salah satunya dapat mendukung kebutuhan pengembangan pariwisata melalui penyediaan produksi kentang. Tanaman kentang kentang merupakan tanaman dataran tinggi yang dapat juga tumbuh dan berpoduksi di dataran medium dengan pemilihan jenis dan teknologi budidaya yang sesuai.

Kawasan dataran medium di Kabupaten Lombok Utara membentang dari Kecamatan Pemenang sampai Kecamatan Bayan, mulai dari Pusuk sampai Senaru, sepanjang kaki dan lereng Gunung Rinjani. Dari keseluruhan kawasan medium, kawasan yang memiliki hamparan sawah yang memenuhi syarat agroklimat tanaman kentang adalah kawasan Santong (Kecamatan Kayangan) dan kawasan Senaru (Kecamatan Bayan). Namun demikian, belum dilakukan upaya pemberdayaan masyarakat pengembangan tanaman kentang di Kabupaten Lombok Utara, khususnya di Desa Santong, sehingga pada kegiatan ini telah dilakukan Pendampingan kepada kelompok Tani di Desa Santong Tujuannya adalah mendampingi pengembangan kentang di desa Santong Kabupaten Lombok Utara terutama aspek budidaya agar petani mampu memahami dan meningkatkan keterampilan untuk pengembangan 
usaha budidaya kentang di dataran medium. Hasil kegiatan ini diharapkan dapat menjadi solusi altrnatif dalam usaha tani hortikultura di kawasan desa Santong.

\section{Metode Pelaksanaan}

\section{Penentuan Lokasi Kegiatan dan Target Peserta}

Kegiatan ini dilaksanakan dikawasan Desa Santong, Kabupaten Lombok Utara. Lokasi yang dipilih adalah Desa yang merupakan sentra hortikultura dataran medium yang pernah sebagai lokasi kaji terap budidaya kentang. Peserta terdiri atas petani dan kelompok tani andalan yang mempunyai pengalaman dalam budidaya tanaman kentang sebelumnya.

\section{Metode Pendekatan}

Metode yang digunakan dalam kegiatan ini adalah Metode Kaji Tindak (Action Research) dengan menerapkan pendekatan Program Tindak Partisipatif (Particpatory Action Program) dari peserta melalui diskusi, dan kerja kelompok pada seluruh kegiatan. Tahapan dalam kegiatan ini meliputi tahapan persiapan, antara lain identifikasi masalah, kemudian survey pendasaran menggunakan metode deskriptif eksploratif. Tahapan pelaksanaan, diawali dengan pelatihan dengan teknik ceramah. Materi pelatihan yang disampaikan meliputi Teknik Budidaya Tanaman kentang; Pengenalan Organisme Pengganggu Tanaman kentang, serta Teknik-teknik Pengendalian Organisme Pengganggu Tanaman.

\section{Penilaian/evaluasi}

Penialaian terhadap kegiatan pengabdian pada masyarakat ini dilakukan dengan berpedoman pada: (1) Kesesuaian antara topik action research yang dilaksanakan dengan keadaan lokasi kegiatan; (2) Kehadiran dan partisipasi para peserta (sasaran) terhadap setiap kegiatan sejak dari persiapan sampai berakhirnya kegiatan mencerminkan keinginan dari peserta untuk mengetahui dan mengadopsi teknologi yang diperkenalkan oleh Tim pelaksana.

Sikap dan tanggapan dari para peserta terhadap kegiatan yang dilaksanakan.

\section{Hasil dan Pembahasan}

\section{Pendampingan Teknik Budi Daya \\ 1. Persiapan Lahan}

Persiapan lahan yang dilakukan adalah mengecek $\mathrm{pH}$ tanah dan air irigasi. Hal tersebut bertujuan untuk mengetahui tingkat kemasaman tanah dan air irigasi pada lahan kentang. Berdasarkan hasil pengecekan tersebut didapatkan bahwa tanah dan air irigasi pada lahan kentang tergolong netral (pH 6 - 7).

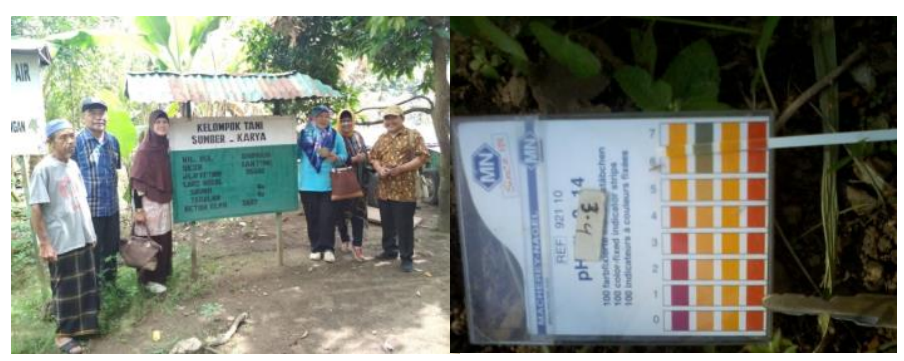

Gambar 1. Persiapan Kegiatan Pengabdian

\section{Pengolahan Lahan}

Pengolahan tanah pada lahan dilakukan sebanyak dua kali. Hal ini bertujuan agar tanah tersebut gembur, memutuskan siklus hidup hama dan penyakit yang ada di dalam tanah serta membantu melancarkan sirkulasi udara dalam tanah dan menghilangkan gas-gas beracun yang kemungkinan ada di dalam tanah.

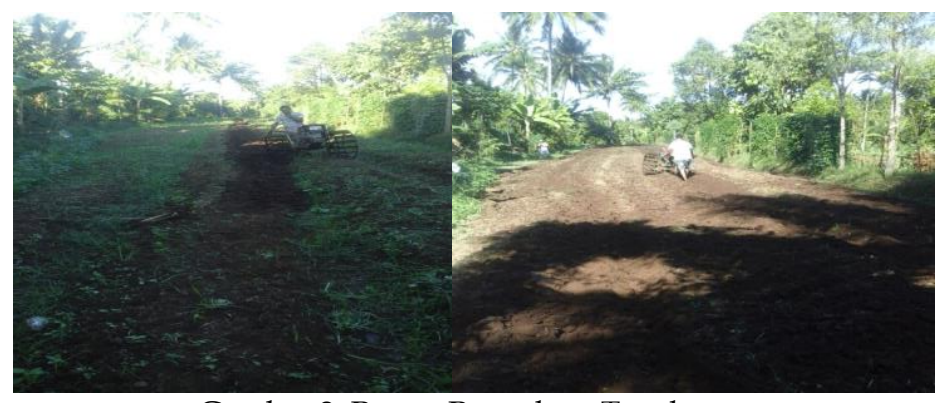

Gambar 2. Proses Pengolaan Tanah

\section{Pembuatan Bedengan}

Bedeng penanaman kentang dibuat dengan tinggi $30 \mathrm{~cm}$ dan lebar $40 \mathrm{~cm}$ dengan jarak antar bedeng $40 \mathrm{~cm}$. Hal ini bertujuan untuk mempermudah pemeliharaan tanaman kentang.

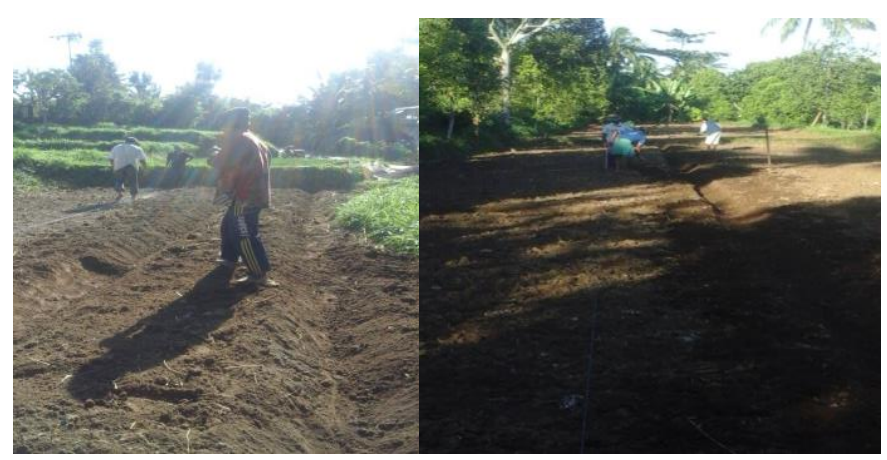

Gambar 3. Proses Pembuatan Bedengan

\section{Penanaman}

Penanaman benih kentang dilakukan dengan cara membuat lubang tanam pada bedengan kemudian benih kentang ditanam. Jarak antar benih 
kentang pada setiap bedengan adalah $30 \mathrm{~cm}$. Pada kegiatan kajiterap ini, masing-masing kelompok melakukan penanaman dengan cara yang berbeda. Kelompok sempakok atas menanam dengan cara menaburkan abu sekam pada lubang tanam kemudian kentang ditanam, sedangkan pada kelompok sumberkarya melakukan penanaman dengan cara biasa.

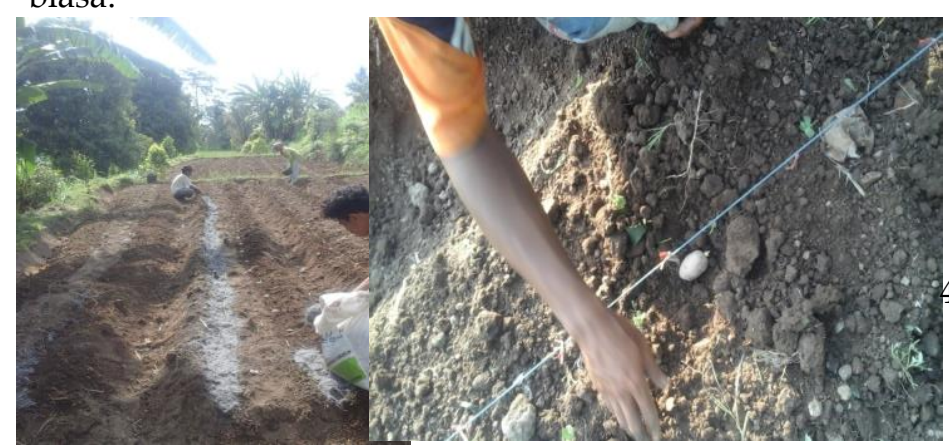

Gambar 4. Proses Penanaman

\section{Pemeliharaan Tanaman}

Pemeliharaan tanaman yang dilakukan meliputi:

\section{1) Pengairan lahan}

Pengairan lahan dilakukan seminggu sekali. Hal ini dikarenakan kondisi tanah pada lahan penanaman bersifat lempung berpasir sehingga memiliki porositas yang tergolong tinggi. Pengairan dilakukan pada malam hari. Pengairan dihentikan ketika tanaman kentang mendekati usia panen (2 minggu sebelum panen);

2) Pemupukan dasar.

Pemupukan dasar dilakukan setelah olah tanah kedua (sebelum penanaman). Pupuk yang digunakan sebagai pupuk dasar adalah: (a) Petroganik: 3 Ton/Ha atau $90 \mathrm{Kg} / 3$ are; (b) NPK : $300 \mathrm{Kg} / \mathrm{Ha}$ atau $9 \mathrm{Kg} / 3$ are; (c) SP36 : $300 \mathrm{Kg} / \mathrm{Ha}$ atau $9 \mathrm{Kg} / 3$ are.

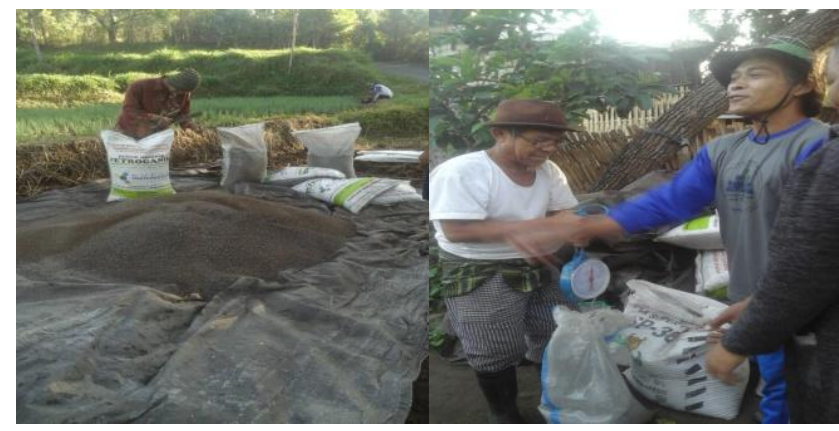

Gambar 5. Proses Pemupukan Dasar

3) Pemupukan Susulan

Pemupukan susulan dilakukan saat tanaman kentang berumur 4 MST (1 bulan). Pupuk yang digunakan sebagai pupuk susulan adalah NPK dengan dosis $350 \mathrm{Kg} / \mathrm{Ha}$ atau $11 \mathrm{Kg} / 3$ are dan ZA dengan dosis $350 \mathrm{Kg} / \mathrm{Ha}$ atau $11 \mathrm{Kg} / 3$ are.

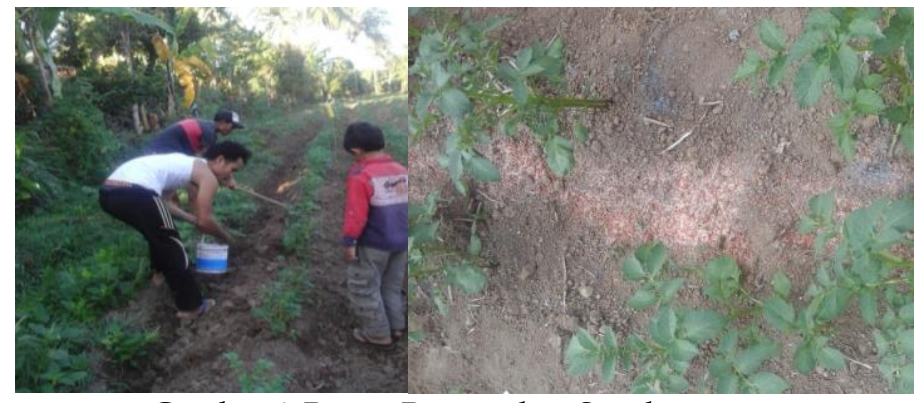

Gambar 6. Proses Pemupukan Susulan

\section{4) Penyiangan}

Penyiangan dilakukan agar pertumbuhan tanaman kentang tidak terganggu oleh keberadaan gulma. Penyiangan dilakukan pada saat tanaman kentang berumur 3 MST.

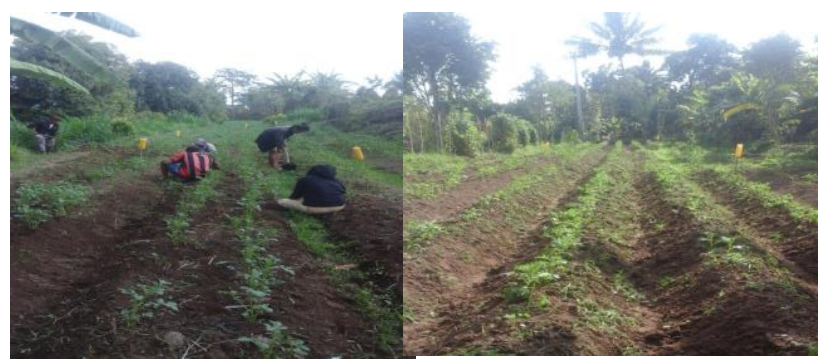

Gambar 7. Proses Penyiangan

\section{5) Pembumbunan}

Pembumbunan bertujuan untuk mengkondisikan tanaman agar tetap tegak. Selain itu, kegiatan ini juga dilakukan untuk menggemburkan tanah disekitar tanaman.

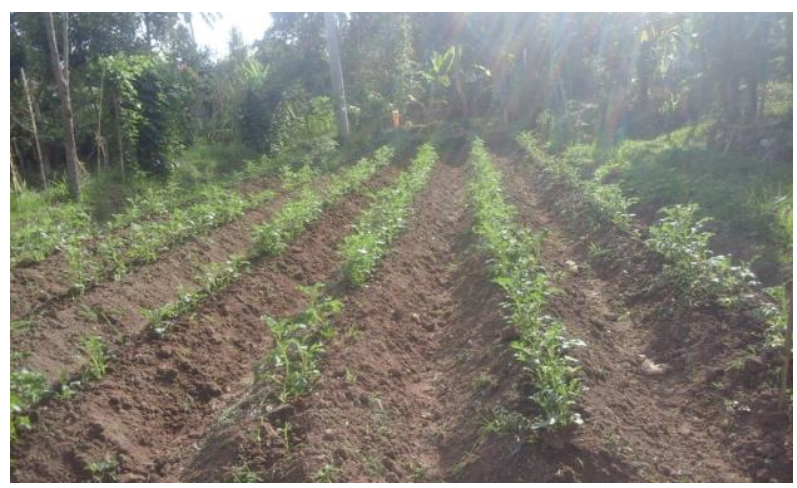

Gambar 8. Proses Pembumbunan

6) Pengendalian Hama

Pengendalian hama pada tanaman kentang dilakukan satu kali seminggu dimulai sejak tanaman berumur 1 minggu. Pengendalian hama tersebut menggunakan Metharizium saat umur 1 dan 6 MST, serta menggunakan BiVi saat umur 2, 3, 
4, 5, 7, 8, 9, 10 MST.Pengendalian biasanya dilakukan petani pada malam hari karena pada saat itu hama menyerang. Selain itu, dilakukan juga pengendalian hama menggunakan perangkap yellow sicky trap.

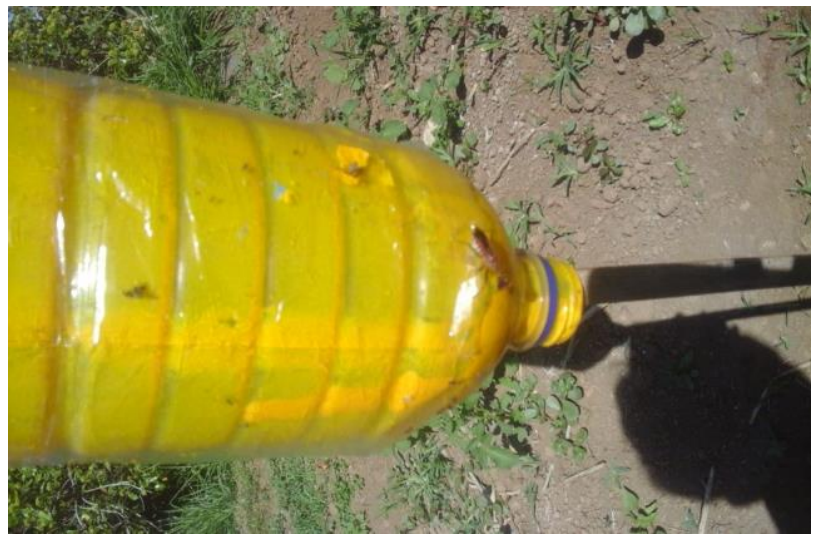

Gambar 8. Proses Pengendalian Hama

7) Pengendalian Penyakit

Pengendalian penyakit pada tanaman kentang dilakukan sejak tanaman berumur 7 MST. Hal tersebut dilakukan untuk mengantisipasi penyakit bor minyak yang akan menyerang saat kondisi lingkungan lembab. Pengendalian penyakit tersebut menggunakan Antracol.

\section{Panen}

Panen dilakukan apabila umbi kentang telah siap untuk dipanen. Umbi yang siap dipanen ditandai dengan kulit umbi tidak terkelupas saat dipencet.

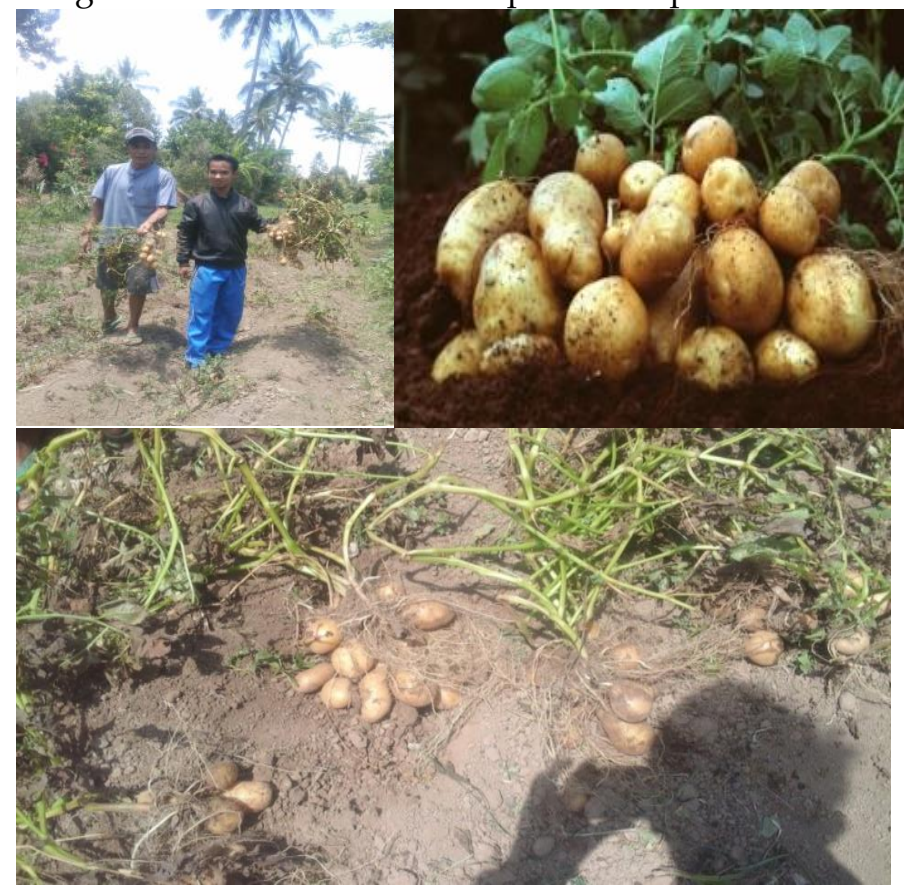

Gambar 9. Proses Panen
Analisa Kegiatan Penyuluhan pada Pendampingan

Kegiatan Penyuluhan pada Pendapingan di Desa Santong, Kabupaten Lombok Utara diikuti oleh petani yang merupakan perwakilan dari masingmasing Kelompok. Proses kegiatan pelatihan ini cukup berhasil berdasarkan indikator kehadiran peserta selama 1 hari penyuluhan, yang dimulai pada jam 8.00 pagi sampai jam 17.00 WITA. Pada awal pelaksanaan kegiatan penyuluhan, pengetahuan dasar peserta tentang teknik budidaya benih kentang bersertifikat masih beragam ada yang cukup baik ada yang masih rendah, rata-rata tergolong rendah karena belum pernah mengikuti pelatihan pelatihan serupa. Sebagian dari mereka menganggap produksi benih kentang bersertifikat sama dengan teknik produksi kentang konsumsi.

Motivasi peserta untuk mengikuti kegiatan pelatihan cukup tinggi dan terus meningkat sampai akhir kegiatan. Hal ini ditandai dengan tingkat kehadiran peserta yang tidak pernah absen, begitu juga antusiasme peserta yang tinggi selama pelatihan dengan semakin banyaknya peserta yang mengangkat tangan untuk bertanya dan berdiskusi. Sebagian besar peserta pelathan cukup kritis dalam memberikan ide, gagasan, dan sharing pengalaman dengan fasilitator maupun dengan anggota peserta pelatihan yang lain.

Beberapa faktor yang dapat mendukung pengembangan kentang di desa Santong kabupaten Lombok Utara adalah sumberdaya lahan. Desa Santong merupakan salah satu desa di kabupaten Lombok Utara yang sebagian besar daerah atau lahan pertaniannya sangat subur, terutama untuk pengembangan hortikultura dataran medium. Semua lahan merupakan lahan yang intensif ditanami berbagai komoditas hortikultura. Hanya saja lahan potensial tersebut belum dikelola dengan optimal. Kondisi lahan tersebut sangat potensial untuk pengembangan kentang dataran medium. Para peserta juga sangat tertarik dengan diperkenalkan beberapa varietas kentang unggul baru dan keinginan yang tinggi dari mereka untuk menanam varietas kentang unggul baru selain yang sduah dikenal selama ini yaitu varitas Granola dan Atlantis.

Keberhasilan dari pelaksanaan kegiatan ini sangat dipengaruhi motivasi dan respon positif masyarakat yang tergabung dalam kelompok tani peserta penyuluhan dan pendampingan untuk menerima adopsi teknologi budidaya kentang, serta mengembangkannya sebagai peluang berusaha dan peluang untuk meningkatkan pendapatan. Di samping itu, dukungan aparat desa dan respon masyarakat di sekitar lokasi sangat baik. Karena kelompok tani peserta pernah mendapatkan pelatihan dari berbagai institusi atas bimbingan instruktur, maka hal ini juga menjadi faktor pendorong, dimana antara peserta 
dengan instruktur sudah saling mengenal secara emosional. Dengan demikian peserta sangat antusias untuk menerapkan teknologi yang diterapkan untuk mencapai tujuannya yaitu budidaya kentang.

\section{Kesimpulan}

Dari hasil dan analisis kegiatan dapat disimpulkan bahwa: (1) Kelompok Tani dan Peserta pendampingan di desa Santong telah meningkat pemahaman dan keterampilan dalam budidaya Kentang; (2) Peserta pendampingan sangat tertarik untuk mengembangkan tanaman kentang sebagai alternative usaha tani hortikultura; (3) Organisme Pengganggu Tanaman (OPT), baik dari kelompok hama maupun penyakit dirasakan menjadi kendala utama dalam budidaya kentang dataran medium di Santong; (4) Masalah penyimpanan dirasakan masih menjadi kendala pasca panen tanaman kentang.

\section{Ucapan Terimakasih}

Diucapkan terima kasih kepada Pemerintah Kabupaten Lombok Utara melalui Dinas Pertanian yang telah banyak memfasilitasi kegiatan ini mulai dari persiapan sampai selesai

\section{Daftar Pustaka}

AAK. (1992). Petunjuk Praktis Bertanam Sayuran. Kanisius: Yogyakarta

Badan Pusat Statistik. (2015). Badan Pusat Statistik Indonesia. Http:// www.bps.go.id. Diakses pada [ 8 April 2015].

BPSB TPH Provinsi NTB. (2015). http://diperta.ntbprov.go.id/data_base/kentan g. htm. Diakses pada [ 8 April 2015].

Idawati. (2012). Pedoman Lengkap Bertanam Kentang, Langkah Mudah Budidaya Kentang dan Kiat Bisnis Olahan Kentang. Pustaka Baru Press. Jogjakarta.

Rukmana, R. (2002). Usaha Tani Kentang Didataran Medium. Kanisius. Yogyakarta.

Sarjan, M., Nikmatullah, A., Windarningsih, M., \& Agus, P.H. (2017). Perluasan dan Pengembangan Produksi Benih Kentang Bersertifikat Nasional di Pulau Lombok dan Pulau Sumbawa. Laporan Penelitian Riset. Unggulan Strategis Nasional tahun kedua. Universitas Mataram

Sarjan, M., Nikmatullah, A., Windarningsih, M., \& Agus, P.H. (2018). Perluasan dan Pengembangan Produksi Benih Kentang Bersertifikat Nasional di Pulau Lombok dan Pulau Sumbawa. Laporan Penelitian Riset. Unggulan Strategis Nasional tahun ketiga. Universitas Mataram
Sembel, D.T. (2014). Serangga-serangga Hama Tanaman Pangan, Umbi dan Sayur. Bayumedia Publishing, Malang

Sinung, R.B. (1989). Production Potato in Indonesia: Prospect for Medium Altitude Production (Eds J. W. T. Bottema et al.). CGPRT Centre, Bogor

Wattimena, G.A. (2006). Prospek Plasma Nutfah dalam Mendukung Swasembada Benih Kentang di Indonesia. Direktorat Perbenihan dan Sarana Produksi. Ditjen Hortikultura, Departemen Pertanian, Jakarta 